\title{
An Analysis of the Creation of Hammer of Witches and the Motivation of the Witch Hunt
}

\author{
Xiaoyue $\mathrm{Hu}$ \\ School of Economics and Management, Beijing University of Chemical Technology, Beijing102200, China, \\ 2019050257@mail.buct.edu.cn
}

\begin{abstract}
Medieval society was misogynistic before 1500 , but why don't we see witch hunt before? What changed around 1500 ? Although majority of witches at this time were women, but nevertheless there were men who were prosecuted for witchcraft too, how do we explain that if we explain all witch hunt by the argument of misogyny? They are all worth considering.
\end{abstract}

Keywords: Witch Hunt, Hammer of witches, Religion, misogyny

\section{INTRODUCTION}

By analyzing the author's life and creative background, this paper hopes to explore the creative motivation of the book. And according to the classic chapter in Hammer of witches, it tries to focus on the research of the persecution of women in the witch hunt and its ideological reasons.

In the original passages selected for this article, the author of Hammer of witches showed strong misogyny. Combined with the fact that women are the main victims in witch hunting, this paper will analyze the influence of misogyny on witch hunt and the real root of witch hunt from the perspective of specific historical conditions.

\subsection{Info about the author(s)}

There are many different opinions regarding the author of Hammer of Witches. Wolfgang Behringer from Germany argued in his work Witches and Witch-Hunts that there was only one author of Hammer of witches, Henricus Institoris (Kramer) [1]. But in La sorcière written by Jules Michelet. He detailed Jacobus Sprenger's story in the relevant chapters and identified him as the author of the book [2]. At the same time, some scholars believe that the book was authored by both of them.

\subsubsection{Henricus Institoris}

Henricus Kramer was born in Schlettstadt, Germany, around 1430 .

He joined the Dominican Order in 1445. Around 1460, he first came to Romand officially began his lifelong career of fighting against heresy. In 1479, he became an inquisitor, and after receiving his doctorate in the same year in Rome, he latinized his surname, changing it to "Institoris".

In 1483, Institoris's monastery received sizeable indulgence from the Pope as a reward for his outstanding performance in the fight against Jamometic. In the years that followed, he traveled extensively, gaining experience in witch trials. But people hated and resisted his persecutions. It hurt his pride and made him very angry so Institoris managed to get the Pope's support. Authorized by the breve Summis Desiderantes Affectibus published in 1484, Institoris planned to start a witch hunt in Innsbruck.

Institoris's work in Innsbruck began in July 1485, but soon after the boycott by the locals, the bishop of Innsbruck immediately ordered the persecution to stop. Institoris was regarded as a fanatic by local citizens, even nobles and the church. For them, he was unacceptable. To add insult to his injury, with the support of the Grand Duke of Tirol, all the female suspects were released. As a result, Institoris's work suffered a big setback.

In December 1486, Institoris hastily sorted out the trials and his experience with witch hunts of the past years and tried his best to prove the existence and threat of witchcraft, in an attempt to turn the defeat into victory. Later, Hammer of witches was published. Perhaps because of Institoris's authority and his talent as a writer, Hammer of witches gained a lot of support under the trend of the printing press. 
For the rest of his life, he intensified his campaign against heresy, denouncing church jurists who stood in his way. His remaining works and manuscripts are all related to criticizing and punishing heresy. Institoris claimed to have executed 200 witches, but he still regarded his work as "not so successful" as he mentioned in his letter.

Institoris died in Bruenn in 1505 and was given a traditional burial by the Dominican order.

\subsubsection{Jacobus Sprenger}

Sprenger was born in Basel in 1436/38, he entered the Dominican monastery in 1452 and became a monk in the second year. In the following decades he devoted himself to the study and teaching of theology. He became a professor of theology in 1478 and was elected to become the dean of theology at the University of Cologne in 1480. At the same time, Sprenger also introduced the Brotherhood of the Rosary into Germany and was known as "Apostle of the Rosary" [3].

Different from the unpopularity of Institoris, Sprenger was a model of Dominic's friars. He also took an active part in political life. He was a leader of Observants, and had been elected deputy abbot of the Cologne monastery and general abbot of the monasteries in the upper Rhine. In 1481 he became an inquisitor of that region. While in Rome, he met a pilgrim from Bohemia who said his son, a young priest, had been cursed by a witch and had been possessed by the devil. Sprenger took them on the road and practiced exorcisms throughout their journey. People saw the mad and miserable condition of the young priest. This caused a stir in Italy, where the rumors of demons were rare. This experience may had indirectly led to his involvement in the writing of Hammer of witches [2].

\subsection{Info about the text}

Hammer of witches is "undoubtedly the best known (many would say most notorious) treatise on witchcraft from the early modern period." [4] The first edition of Hammer of witches was published in Germany in 1487 and has since been republished in various places.

Although it did not directly bring the witch hunt to a climax, it certainly led to future conflicts and had an impact on later generations.

If defined strictly by the fall of the Eastern Roman Empire, the Middle Ages ended in 1453 with the gunfire of Ottoman army and the fall of Constantinople. If so, Hammer of witches cannot be defined as a medieval work, but it has Strong characteristics of the times. To explore its context and historical information, people today need to go back much further and focus on a few big things that happened before.

\subsubsection{Black Death}

When it comes to medieval Europe, people usually talk about the Black Death. The Black Death, which broke out in the middle and late 14th century, had a great influence on the development of Europe, and some Western scholars consider it as "the watershed between the middle and late Middle Ages" [5].

The most immediate result of the Black Death was the destructive shrinkage of the population. And the Little Ice Famine, at the same time, made matters worse. After the Black Death subsided, the population in some places (notably Italy, the commercial center of Europe) fell by 50 to 60 percent, or even as much as 70 percent [6]. The scarcity of rural population and the desolation of lands made smallholders more valuable. This led to or at least contributed to the collapse of serfdom. At that time, the pursuit of luxury in the city emerged. As prices fell and disposable income increased after the Black Death, people were able to pursue a better quality of life. During this period, the urban capitalism grew.

"The changes in the economic foundation lead, sooner or later, to the transformation of the whole, immense, superstructure." [7] Under such conditions, people began to pay more attention to themselves. In addition to the economic impact mentioned above, this mentality was also reflected in the art. Many of the art works of that period reflect people's desire for a better life [8]. Meanwhile, the background most closely associated with the appearance of Hammer of witches is the impact of the Black Death on religion. The terrible Black Death had shaken the absolute authority of the church. The death of innocent believers and clergies shook the basic belief that the plague was God's punishment for sinners [9]. The Christian religion and the Church were claimed to be omnipotent, but in the face of disaster they failed to save the world. This reduced the church's control over popular belief. Under such circumstances, the church was eager to restore its prestige. Thus, the elimination of heresy became an important way to achieve this goal.

The plague also damaged human relations. The uncertainty of life and death made many people selfish, and the relationship between neighbors was much weaker than before. Some scholars believe that this is one of the reasons why people were willing to talk about witches at that time [10]. All of these foreshadowed the spread of the witch hunt.

\subsubsection{The Western Schism and the conciliar movement}

Disputes over the legitimacy of several popes in the Roman Catholic Church led to the Western Schism (1378-1417). French Pope Gregorius Xi died in Rome in March 1378. With the support of the secular feudal rulers of Italy and France, the church elected two popes, one in 
Rome and the other in Avignon. For the next forty years, the divided sides did not recognize each other's status [11] [12]. At the Council of Pisa in 1409, the prelates ousted two current popes and elected a new one. This ridiculously created a situation of confrontation between the three forces. The real cause of the Western Schism was the power struggle of those feudal rulers, rather than the differences in doctrines and canons. It was the Council of Constance in 1418 that finally put an end to the Western Schism, a compromise was reached and it was decided that a new Pope would be elected by both the archbishops and the delegates.

Since the Western Schism, the Pope's influence and importance had declined. The papal power was also reduced from the western European world to central Italy [13]. The papal authority was largely destroyed.

And the conciliar movement, with the aim of "replacing the Pope with the council of the church as the supreme authority in the church", did not stop after the Council of Constance. In 1431, at the Council of Basel, there was a strong confrontation between the Pope and the Council. This long and tortuous dispute ended in 1449 and it marked the end of the conciliar movement. (Most of the council's ideas became law in France, ensuring that France was freed from papal interference and its heavy taxes, and setting the stage for a relatively independent religious power in France. But in Germany, the home to Henricus Institoris, these reforms have not been implemented. [13]) After all this, the subsequent popes had a very different social standing and mindset from their predecessors [11]. They turned to the politics of the Papal State.

The change of papal status and the chaotic political environment foreshadowed the corruption and tyranny of Pope Innocent VIII. For all the reasons described above, as well as his own ill health, the politics of the church during his reign were dominated by Giuliano della Rovere, the nephew of Pope Sixtus IV [14]. In order to consolidate the papal rule, strengthen the authority of Christianity and exclude dissent, Pope Innocent VIII released " Summis Desiderantes Affectibus " in the first year of his reign. It is worth mentioning that, according to scholars, this breve was probably issued at the request of Henricus Institoris [15]. So, it could be said to be a mutually beneficial cooperation between the Pope and Institoris. Institoris put this breve in the preface to the Hammer of the Witches and it certainly added legitimacy and authority to his book.

In this breve, the Pope explicitly praised the work of Institoris, emphasized the atmosphere of terror and explained the urgency of the hunt. The breve encouraged the European witch hunt. However, Pope Innocent VIII did not specify the sex of the targets of persecution [16]. So Institoris's creation is further biased and not entirely out of loyalty to the Pope and doctrine.

\subsubsection{The Politicization of Universities}

It was a time when access to knowledge was relatively limited, therefore, universities played an even more important role in the field of ideology and culture than they do nowadays. In the late Middle Ages, the political turmoil between the religious and secular political powers motivated the both parties to seek for a greater influence projection on universities.

From the 14th century to the 15 th century, universities were becoming more region-centric and were under a tighter control from the secular authorities [17]. Being more region-centric means that universities gradually lost the international character they had in the early days and focused on recruiting students from their own ethnic group and region. The aim was to promote the economic development of the region, while controlling the flow of talent and the minds of citizens. Both Institoris and Sprenger may have been influenced by this situation. As Germans, they both got their first degrees in Cologne. At the same time, due to the strengthening of state control over universities in this stage, the autonomy of universities was gradually deprived. The King of France gradually abolished the privileges of the University of Paris between 1437 and 1449 [17].

Excessive interference placed severe limits on the freedom of thought and action of universities in the late Middle Ages. In this academic environment, the education process had a strong purpose. Teachers and students came to universities not only for knowledge, but also for social status and benefits.

In the late Middle Ages, because of the struggle between secular and clerical power for the university, those universities represented by the University of Paris were somehow too keen on religious and secular political affairs overly [19]. Such an educational environment had a subtle influence on the concepts and principle of Institoris. Institoris was a typical member of the university during that period, who was devoted to religion and had obvious political ambition. Due to his own interests and strong academic ability, he became the pioneer of university members to participate in politics.

\subsubsection{Something else worth noting}

The general social environment of the late Middle Ages exacerbated the anxiety and desire for salvation of the Christian community, leading to the activity of various ideas and doctrines, such as individualism, mysticism, and asceticism. Mysticism became very important in the fourteenth and fifteenth centuries. It also led to a distortion of the indulgences rule [20]. What these phenomena had in common was that they reflected people's quest to be saved. This mass mindset also led to a growing fear and disgust of evil and heresy. 


\section{SUMMARY OF HAMMER OF WITCHES P159-173}

The first paragraph raises some questions about sorceresses who were subject to the demons and how they did their deeds. The emphasis is on demons' formation (including what they are made of) and their influence on women. But the author left these questions unanswered. Instead, he raised another question: Why were women more likely than men to violate their beliefs? Next, the author had a detailed interpretation of this question.

The author gave the doctor's explanation first: There were three elements in the world that did not know how to maintain a middle course in terms of goodness or evil.

( The editor of the book argues in the notes that this passage is in fact irrelevant to the central issue. I also agree with this view. ) The author explained both the good and the bad sides of the tongue, churchman and .woman. The language quoted in the first paragraph about "women" emphasized the evil of women. The second paragraph cited three biblical figures as the examples of heroines. The author emphasized that good women should be good for men.

Then the author gave three reasons from the perspective of women themselves: Women are prone to believing, it gives the demons chances to set in; because the natural temperament is not stable, women are easy to incur the disembodied spirits; women cannot express themselves well. They also lack physical strength and resort to sorcery as a means of revenge.

The following is the reason of the third group. They believed that women were good at cheating and doubting. And women were deficient in both mental and physical strength and would use witchcraft against those they envied.

Later passages cited numerous stories of bad women, making a strong case for the inherent imperfection of women in order to justify the evil of women as the basis for their practice of witchcraft. And it extended to marriage, with the alarmist message that women ruined happiness. Then from the family to the country, the author put the responsibility for the decline and fall of the kingdom on women completely.

The next part is a full-on attack on women: The author compared women to ugly monsters and thought that men would communicate with God without women. He also compared the women's voice to the song of the Sirens, and thought that women were good at lying and hurting others with words, they strived to please men. All the behaviors of women were vanity of vanities.

The author concluded that "Everything is governed by carnal lusting". He also claimed that women cavorted with demons to satisfy their lust. This leads the to the second topic: What sort of women are more often found to be superstitious and sorceresses?

The author put forward three faults: lack of faith, ambition, and debauchery. The following paragraph mainly criticized the lewdness of women and points out that this trait always made negative effects on men.

\section{Terminology}

1. Indulgence: In 1313, the church began selling indulgences in Europe. People could offset their sins by buying indulgences.

The people who sold indulgences were called "pardoners".

2. Breve: Directives issued by the Pope.

3. Schism: Divide the church

4. Sorceress: The word means which.

5. Sorcery: The mystical power used by witches to influence reality.

6. Heresy: Any of various religious sects contrary to orthodox Christian theology.

\section{ARGUMENTATION}

As a notorious, far-reaching encyclopedia of witch hunt, the contents of Hammer of witches can be roughly divided into three parts: the first part deals with theological issues, proving the existence and harm of witchcraft, the second part focuses on the prevention of witchcraft, the third part describes the procedure of prosecution of witches in religious and secular courts as well as the trial process and methods. Hammer of witches quoted extensively from the Bible and other writings. It can be seen as an amalgamation of previous demonology without much original content. However, one of the major features of Hammer of witches is to emphasize the relationship between witchcraft and women, which may be related to the author's own prejudice. Through reading, it is easy to see the author's malice and attack on women on all aspects.

The Summary section above summarized a chapter revealing many misogynistic features Next, based on this chapter, I will analyze the reasons for targeting women in witch hunts, along with the development of misogyny and the religious and social conditions of that time.

To understand the underlying causes, it is necessary to trace the roots of misogyny, especially from a religious perspective. From the origin, it is probably because of the prejudiced interpretation of the Bible. In the Genesis myth, God created Eve out of Adam's rib, so the idea was that females were 'by-products' of males, and males were of a dominant status. In addition, Eve lured Adam to eat the forbidden fruit and they were then expelled from the Garden of Eden. Therefore, women represented by Eve 
were regarded as the cause of human misfortune. Apart from the scripture, Christianity also has a long history of degrading women in practice. In the Middle Ages, both celibacy and asceticism put men and women in opposite directions, which accelerated the spread of this misogynist concept. By the time of Institoris's life, negative views of women have made religious people to associate females and witchcraft even more closely [21].

\section{1. "Born Imperfect"-The natural defects of women}

Hammer of witches suggested that women were easily seduced by demons because of their weaknesses. The author tried to show that women are born with defects in body, mind, and soul through biased and purposeful quotations from the Bible. (In fact, to prove that women are inherently imperfect, men of later generations have used more than theological perspectives. In short, such views are not unique to that time, but have a long history [22].)

The claimed imperfection of the female body was mainly reflected on their weaker body strength $_{\overline{5}}$ and the existence of the menstrual period. For instance, he quoted the idea from the Old Testament that the menstrual period and the puerperium of women were regarded as "unclean".

As for mind and soul, the view was that women were ignorant and vulnerable to devils. The rationale behind was that the natural temperament of women was not stable, and as a result it's easy for them to incur disembodied spirits. The author believed that women had these natural defects and therefore were inferior to men on all aspects. Those who could be superior to men in any case would be classified as witches.

\subsection{The harmful characteristics of women}

In this chapter, according to the author's description, there were various other characteristics of women that were also evil, which should arouse vigilance. The author launched an attack on women from the aspects of appearance, voice, and behavior. The author emphasized the harm of these characteristics of women, which could be summarized as: they will bring temptations to men and lead to hindrance of men's practice. After reading through the whole chapter, we could find that the author, after emphasizing the danger of "temptation", attributed all the mistakes to the temptation itself, and failed to criticize and educate those who could not resist temptation, which seemed to be shirking responsibility.

In my opinion, all the negative characteristics of women mentioned in this section were actually pointing to religious heresy. If all temptations contrary to doctrine and practice could be regarded as heresy, then this feeling of disgust and resentment could be explained as a reflection of the author's aversion to everything contrary to the doctrine and his fanaticism for religion. And the religious crackdown on heresy at the time.

\subsection{The expectations of women under the negative female view}

In one particular section, the author devoted a large paragraph to "good women" before embarking on a bigoted discourse. At first glance, this section may seem deliberate in the malevolent language, but the core idea of this section is still patriarchal and self-interested. The quotes from Corinthians and Ecclesiasticus all emphasize that a good woman should be good for a man "If a woman has a husband and he agrees to live with her, let her not send away her husband. For an unbelieving man is made holy through a faithful woman." The husband of a good woman is blessed." [4]. These statements later became the theological basis for the church to limit the religious power of women [23]. They regarded women as tools for men to improve their spiritual practice and their appendages.

Under the influence of this kind of thinking, men's expectations for women in the social environment could be summarized as "meeting their needs". Once women failed to meet their expectations, women will be responsible for most of the mistakes. For example, the author clearly stated in the article that marriage was useless and women would lead to family misfortune. He even held women responsible for the decline and destruction of all nations [4].

\subsection{A tradition of Patriarchy}

The misogyny of Hammer of witches is not only religious misogyny, but also political misogyny. It's highly purposeful, and the witchcraft persecution it led was closely related to the male status. In the late Middle Ages, women's activities in the social and economic fields went beyond the boundaries of the patriarchal society. Especially, women were closely related to economic production, and some women could even hold certain economic power, and noble women could get involved in the public domain. Women tended to break away from the shelter of men and became independent. This was due to the fact that women in most parts of Europe at that time enjoyed the right to inherit.

This was certainly not the kind of thing a traditionally patriarchal society would want to see. Restoring their control over women had become an appeal for some men in this situation. It was undeniable that the main victims in the witch hunt were women, and the witch hunt was also a means to consolidate the patriarchal position to some extent.

Although there is a serious misogyny in Hammer of witches, and many of the authors' malevolence towards 
women has been discussed above, it is worth noting that misogyny was not the only conception of women in the Middle Ages. Christianity's protection of women, and women's real rights are undeniable. The real situation needs to be analyzed by region and class.

While women were the main victims of the movement, many men were also persecuted. The proportion of men victimized varied greatly from place to place, accounting for $20-25 \%$ in general and as high as $75 \%$ in some regions [24]. Misogyny cannot be used to fully explain witch hunts, whether it was primarily aimed at women or heresy is still debatable. In short, under the cover of misogyny, the targeting of women in Hammer of witches can be explained by its religious ideological roots. In the background information above, we have already analyzed the dangers of the church in this period, such as the weakening of its faith and its power. The extreme words of Hammer of witches can also be attributed to the general fear of heresy in the church at the time, the urge to fight heresy and defend the church. It was determined by the political and religious circumstances of the time. The ultimate goal of Hammer of witches and witch hunt in the fifteenth century was to consolidate the authority of the church.

But from a perspective of women, the creation of the Hammer of witches at least intensified the persecution against women. As an important part of human beings, women should be given due respect and rights. Only when a society truly respects women can it develop and progress continuously especially in modern times.

\section{CONCLUSION}

Through a typical chapter in Hammer of witches, this paper discusses the historical inevitability and contingency of the witch hunt.

Based on the targeting of women in the witch hunt, the view of women is an important part of this paper. However, this paper is not limited to the analysis of misogyny in the Middle Ages, but extends it from multiple perspectives based on the content of historical materials.

At the same time, this paper considers the political, economic, and cultural characteristics under the background of that time and strives to place ourselves in a more comprehensive and real society in the 15 th century. It starts from the background of the book "The Witch's Hammer" to think and study the deep reasons for the formation of the witch hunt. Therefore, under the appearance of misogyny, we can see the deeper motive of witch hunt: the political appeal of the religious system to consolidate its rule.

At present, China's domestic research on the European Middle Ages, especially on religion, is somewhat lacking. People generally have a one-sided understanding of this era. Even due to the influence of various art works, "witches" have formed an inherent vicious and weird impression in people's minds, and people always hold a curious attitude towards witchcraft. There is also a tendency to demonizing witch hunt and to associate all the bad things with the "Dark Middle Ages", ignoring the nature of the problem and other important features of this historical period. There is an urgent need for us to break down prejudices and put historical facts in perspective.

History and historical knowledge are essentially a kind of self-knowledge. It is hoped that through the small window of "Witch Hunt", people can think more about human beings themselves and the future development of human society.

\section{REFERENCES}

[1] Behringer, Wolfgang. Witches and Witch-Hunts. Beijing: Peking University Press, 2018.

[2] Michelet, Jules. La sorcière. Shanghai: Shanghai Academy of Social Sciences Press, 2019.

[3] Broedel, Hans Peter. The Malleus Maleficarum and the Construction of Witchcraft: Theology and Popular Belief. Manchester: Manchester University Press, 2003.

[4] Hammer of witches

[5] Li, Xiaoguang. "The Black Death and Social Transformation of 14th-15th's Europe", Master's thesis, Guangxi Normal University, 2006.

[6] The Cambridge Economic History of Europe 1. Beijing: Economic Science Press, 2002.

[7] Marx, Karl Heinrich. A Contribution to the Critique of Political Economy. Berlin: Dunker Press, 1859.

[8] Huizinga, Johan. The autumn of the middle ages. Guilin: Guangxi Normal University Press Group, 2008.

[9] Bible: Old Testament 2 Samuel

[10] Yan, Xue. Analysis of the reasons for people to denounce witches during witch persecution. Master's thesis, Liaoning Normal University, 2015.

[11] Judith M. Bennett, C. Warren Hollister. Medieval Europe-a short history. Shanghai: Shanghai Academy of Social Sciences Press, 2007.

[12] François Pierre Guillaume Guizot. The history of civilization in Europe. Beijing: Taihai Press, 2016.

[13] Qiao, Yongmei, “A study for the rise and practice of Conciliar Movement in the late Medieval", Master's thesis, East China Normal University, 2012.

[14] Liu, Minghan. Biography of the Popes. Beijing: 
People's Publishing House, 2013.

[15] Sun, Yue. "Hammer of witches and the Witch-hunt". PhD diss, Capital Normal University, 2011.

[16] Pope Innocent VIII, Summis Desiderantes Affectibus, 1484.

[17] Fang, Yong. "Discussion on the Rise of Universities in Europe During the 11-15th Century". Master's thesis, Hunan Normal University, 2006.

[18] Rashdall, Hastings. The universities of Europe in the middle ages. Chongqing: Chongqing University Press, 2011.

[19] Li, Hailong. "Why did universities rise in the west". PhD diss, Nanjing Normal University, 2016.

[20] Wang, Luyao. "Late medieval Christian female mysticism". Master's thesis, Minzu University of China, 2013.

[21] Li, Guizhi. The development and influence of misogyny in medieval Europe. Historiography Quarterly, no. 4 (2016). 100-112+160

[22] Morgan, Elaine. The descent of women. Beijing: SDX Joint Publishing Company, 2016.

[23] Liu, Xincheng. A study of medieval social history in Western Europe. Beijing: China Renmin University Press, 2006.

[24] Zhang, tao. Analysis of the targets killed in witch hunts. Oriental Enterprise Culture, no.5 (2010). 196

[25] Li, Jinchao. Medieval Witch Culture from the Perspective of Feminism. Social Science Review, no.9 (2016). 117-121

[26] Xu, Shanwei. Why were women the main victims of witch hunts in early modern Europe. Historiography Quarterly, no. 5 (2015). 157-172+193 